Jurnal Penelitian dan Pengabdian Kepada Masyarakat Bidang ilmu Pendidikan

\title{
Pengaruh Penggunaan Teknik Ice Breaking terhadap Hasil Belajar Matematika Siswa Sekolah Dasar
}

\author{
Titi Pujiarti \\ Program Studi Pendidikan Guru Sekolah Dasar, STKIP Yapis Dompu \\ E-mail: titipujiarti1988@gmail.com
}

Article History: Received: 2022-01-11 || Revised: 2022-02-01 || Published: 2022-02-08

Sejarah Artikel : Diterima: 2022-01-11 || Direvisi: 2022-02-01 || Dipublikasi: 2022-02-08

\begin{abstract}
This study aims to determine the effect of using the Ice Breaking technique on the mathematics learning outcomes of fifth grade students at SDN Mpuri. This study is an experimental study with a non-equivalent group design. The population of this study were all students of SDN Mpuri, aggregate 120 students. Samples were taken using Pre Experimental Design in the form of One Group Pretest Posttest Design. The sample in this study was the five grade students of SDN Mpuri with aggregate of 30 students. The data collection method used is a test method in the form of a description test. The data analysis technique used is t-test. The results of the t-test analysis showed a significance level of $0.017<0.05$ indicating that there was a significant difference before and after treatment. So that HO is accepted and Ha is rejected, meaning that there is an effect of applying the Ice Breaking technique on mathematics learning outcomes for five grade students at SDN Mpuri.
\end{abstract}

Keywords: Development, Ice Breaking technique, Learning Outcomes, Mathematics

\begin{abstract}
Abstrak
Penelitian ini bertujuan untuk mengetahui pengaruh penggunaan teknik Ice Breaking terhadap hasil belajar matematika siswa kelas V SDN Mpuri. Penelitian ini merupakan penelitian ekspeerimen dengan rancangan kelompok non ekuivalen. Populasi penelitian ini merupakan seluruh siswa SDN Mpuri yang berjumlah 120 siswa. Sampel diambil menggunakan desain Pre Experimental Design bentuk One Group Pretest Postest Design. Sampel dalam penelitian ini adalah siswa kelas V SDN Mpuri dengan jumlah 30 siswa. Metode pengumpulan data yang digunakan adalah metode tes berbentuk tes uraian. Teknik analisis data yang digunakan adalah ujit. Hasil analisis uji-t menunjukkan tingkat signifikansi 0,017<0,05 menunjukkan bahwa terdapat perbedaan signifikan sebelum dan sesudah pemberian treatment. Sehingga H0 diterima dan Ha ditolak, artinya ada pengaruh penerapan teknik Ice Breaking terhadap hasil belajar matematika pada siswa kelas V SDN Mpuri.
\end{abstract}

Kata kunci: Pengembangan, Teknik Ice Breaking, Hasil Belajar, Matematika.

\section{PENDAHULUAN}

Hakikatnya pendidikan dapat dijadikan sebagai upaya pemberian wawasan dalam hal keterampilan dan keahlian tertentu kepada individu guna mengembangkan bakat serta kepribadian. Pendidikan memiliki peran yang penting dalam membangun sebuah peradaban dan pendidikan menentukan apakah penerus bangsa dapat memberi sumbangsi atau tidak terhadap negaranya sendiri. Pendidikan adalah usaha sadar yang terencana untuk mewujudkan suasana belajar dalam proses pembelajaran untuk perserta didik secara aktif menggembangkan potensi dirinya guna memiliki kekuatan spiritual, keagamaan, pengendalian diri, kepribadian, kecerdasan, akhlak mulia, serta keterampilan yang dimiliki oleh dirinya dan masyarakat, selain membenahi sistem pendidikan, proses pembelajaran juga harus berlangsung secara efektif agar siswa dapat memiliki hasil belajar yang tinggi, karena tidak bisa di pungkiri bahwa hasil belajar siswa di pengaruhi oleh proses pembelajaran yang inspiratif, menyenangkan, menantang, memotivasi peserta didik untuk berpartisipasi aktif serta memberikan ruang yang cukup bagi prakarsa, kreativitas, dan kemandirian yang sesuai dengan bakat, minat, dan perkembangan fisik serta psikologis peserta didik. 
Pendidikan Sekolah Dasar merupakan wadah pembentukan karakter siswa, selain itu juga keterampilan siswa pada jenjang tersebut sangat baik untuk dilatih khususnya mata pelajaran Matematika. Berdasarkan pengamatan yang dilakukan di SDN Mpuri, peneliti menemukan beberapa masalah yang terlihat, diantaranya siswa kurang termotivasi dan bersemangat selama pembelajaran berlangsung. Hasil wawancara yang dilakukan kepada wali Kelas IV mengatakan bahwa pada mata pelajaran Matematika peserta didik masih belum maksimal sesuai dengan standar KKM dalam pembelajaran Hasil belajar pada mata pelajaran Matematika kurang dari 70. Faktor penyebab adalah Kurangnya keterlibatan aktif siswa dalam mengikuti Mata Pelajaran Bahasa Indonesia sehingga siswakurang mampu mengembangkan imajinasi, serta siswa tidak bersemangat dalam mengikuti pembelajaran.

Upaya meningkatkan keterlibatan aktif siswa, Pembelajaran di kelas harus dimulai dengan awal yang baik, penuh semangat, menyenangkan dan menumbuhkan suasana pembelajaran yang menyenangkan. Konsentrasi dan perhatian siswa akan terfokus pada guru sehingga diharapkan siswa dapat mengerti materi pembelajaran.yang dilaksanakan akan optimal. (Ika Febriandari 2018). Ice Breaking adalah suatu teknik yang dilakukan dalam kelas untuk mengubah situasi yang membosankan, mengantuk dan tegang serta kurangnya konsentrasi menjadi ceria dan menyenangkan.Teknik Ice Breaking yang dimaksud dalam penelitian ini berupa game education, brain gym, dan humor.

Penggunaan teknik Ice Breaking dalam proses pembelajaran cukup penting. Hal ini dapat membantu siswa untuk keluar dari suasana ketegangan dan kebekuan saat menerima pelajaran dari guru sehingga informasi yang disampaikan guru akan diterima langsung oleh siswa melalui sel saraf dan dibawa ke otak. Kondisi seperti itulah yang membawa siswa mulai bergerak dengan cara menanyakan sesuatu yang belum dipahamisehingga proses komunikasi dalam pembelajaran mulai efektif. Dengan diterapkan ice breaking ini adalah untuk menghilangkan kejenuhan, kebosanan serta rasa ngantuk dengan hal sederhana yang dilakukan oleh setiap orang tanpa perlu keterampilan yang mumpuni. (Sapri.2022). Hal inilah yang diharapkan muncul dalam setiap kegiatan pembelajaran di kelas karena apabila siswa senang dalam pembelajaran di kelas maka mereka akan semakin aktif. Semakin aktifnya siswa terlibat dalam kegiatan pembelajaran maka kemampuan otak mereka dalam menangkap materi pembelajaran juga akan semakin berkembang. Berdasarkan penelitian yang dilakukanoleh para peneliti sebelumnya dapat disimpulkan bahwa penggunaan teknik Ice Breaking berpengaruh terhadap hasil belajar siswa, khususnya pada SDN Mpuri. Maka peneliti bermaksud hendak meneliti dengan judul "Pengaruh Penggunaan Teknik Ice Breaking (Game Education, Brain Gym, dan Humor) pada mata pelajaran Bahasa Indonesia terhadap hasil belajar siswa kelas V SDN Mpuri".

Ice breaking sangat diperlukan dalam proses pembelajaran di kelas untuk menjaga stamina emosi dan kecerdasan berpikir siswa. Ice breaking diberikan untuk memberikan rasa gembira yang bisa menumbuhkan sikap positif siswa dalam proses pembelajaran. Pembelajaran dengan Ice breaking memberikan stimulus agar siswa mau belajar secara terus menerus sehingga menghasilkan/produk yang kedepan mampu diimplementasikan dalam kehidupan nyata. Ice breaking sebagai alternatif peralihan situasi dari membosankan, mengantuk, menjemukan, dan tegang menjadi rileks, bersemangat, tidak membuat mengantuk, serta ada perhatian dan ada rasa senang untuk mendengarkan atau melihat guru. Menurut Dananjaya (2013: 233) bahwa Ice Breaker adalah Suatu kegiatan pemanasan yang dapat memecahkan suasana yang dingin, beku, dan kaku menjadi hangat, mencair dan rileks. Suasana kebekuan dalam pembelajaran di kelas akan mengalami perubahan menjadi suasana menyenangkan jika otak diarahkan dalam kondisi gelombang tertentu. Hal yang sama dikemukakan oleh Chatib (2013: 99) bahwa adalah Ice Breaking sangat ampuh untuk mengembalikan konsentarasi dengan mengarahkan otak masuk ke zona alfa, yaitu kondisi relaks yang dapat mendorong aliran energi kreativitas, perasaan segar dan sehat sehingga suasana akan kembali santai dan menyenangkan sehingga siswa memahami suatu informasi ketika belajar.

Lebih lanjut ditegaskan oleh Porter (2012: 22) mengemukakan bahwa "saat anak belajar dalam suasana menyenangkan maka otak akan mekar dan berkembang seperti spons yang membuat siswa mampu menyerap pelajaran dengan mudah dan cepat". Hal inilah yang diharapkan muncul dalam setiap pembelajaran di dalam kelas karena apabila siswa senang dalam mengikuti pembelajaran maka pembelajaran di kelas akan semakin aktif. Semakin aktif para siswa terlibat 
dalam kegiatan pembelajaran maka kemampuan otak mereka dalam menangkap materi pembelajaran juga akan semakin berkembang. Salah satu cara yang tepat demi untuk mewujudkan hal tersebut dapat dilakukan dengan menggunakan teknik Ice Breaking dalam setiap proses belajar mengajar, berdasarkan pendapat para ahli di atas maka dapat disimpulkan bahwa Teknik Ice Breaking adalah tehnik yang mampu merubah pola semangat belajar anak dengan berbagai macam game didalamnya dan mampu merangsang motivasi siswa dalam menangkap materi dan memahami lebih cepat materi diajarkan, adapun langkah-langkah ice breaking yang akan di terapkan yaitu:

a. Siswa diajak membentuk lingkaran besar (dikondisikan sesuai keadaan kelas).

b. Guru menjelaskan tujuan permainan yaitu untuk membangun imajinasi, melatih keberanian berkomunikasi, dan melatih kreativitas berfikir.

c. Guru memberikan kesemptan untuk menentukan tema yang akan dibuat cerita secara bersamasama.

d. Guru menyiapkan catatan untuk mencatat cerita siswa.

e. Siswa pertama dipersilahkan bercerita satu kalimat yang sesuai dengan tema yang sedang dibahas kegiatan bercerita di teruskan oleh siswa yang lain disebelah kanannya.

f. Guru mengatur agar cerita jangan sampai selesai sebelum siswa terakhir memberikan ceritanya.

g. Cerita berakhir jika semua siswa sudah bercerita minimal dalam satu kalimat untuk masingmasing siswa.

Keberhasilan siswa dalam belajar dapat dipengaruhi oleh faktor dari dalam dan luar individu. Siagian (2012:123), Hasil belajar adalah perubahan perilaku peserta didik berdasarkan pengalaman yang dilakukan peserta didik dalam berinteraksi dengan lingkungan (Pranada \& Hadiyanto, 2019), sehingga hasil belajar merupakan perubahan perilaku yang meliputi kognitif, afektif, dan psikomotorik yang dimilki oleh peserta didik. Berhasil tidaknya peserta didik dalam proses pembelajaran dapat dilihat dari hasil belajar siswa, berdasarkan uraian di atas dapat disimpulkan bahwa hasil belajar matematika adalah perubahan hasil belajar yang dilakukan oleh peserta didik berdasarkan pengalaman belajar dan dapat dipengaruhi oleh bebrapa macam faktor baik dari dalam maupun diluar individu peserta didik.

\section{METODE PENELITIAN}

Jenis penelitian yang digunakan dalam penelitian ini adalah penelitian eksperimen. Dalam penelitian ini menggunakan desain Pre Experimental Design bentuk One Group Pretest Postest Design, yaitu desain yang melibatkan satu kelompok sebagai kelompok eksperimen, dalam penelitian ini observasi dilakukan sebanyak dua kali yaitu sebelum dan sesudah eksperimen. Observasi yang dilakukan sebelm eksperimen yaitu $\boldsymbol{O}_{1}$ dan sesudah eksperimen yakni $\boldsymbol{O}_{2}$. Perbedaan antara $\boldsymbol{O}_{1}$ dan $\boldsymbol{O}_{2}$ yakni $\boldsymbol{O}_{2}-\boldsymbol{O}_{1}$ diasumsikan merupakan pengaruh dari perlakuan tersebut.

Dalam penelitian ini terdapat 3 tahap pelaksanaan yaitu pretest, treatmen, dan posttest. Populasi dalam peneliti dengan sampel pada penelitian ini adalah siswa kelas V SDN Mpuri tahun ajaran 2021/2022 yang berjumlah 30 siswa.Teknik yang digunakan untuk memperoleh data dalam penelitian ini adalah observasi, tes, dan dokumentasi. Lembar observasi digunakan untuk mencatat kejadian-kejadian atau perubahan dan reaksi dari siswa selama mengikuti pembelajaran dengan menggunakan teknik Ice Breaking secara langsung terhadap subyek penelitian. Tes digunakan dalam penelitian ini yaitu tes tertulis dalam bentuk isian dengan tujuan untuk mendapatkan data mengenai pengaruh penggunaan teknik Ice Breaking terhadap hasil belajar Bahasa Indonesia siswa. Dokumentasi yang meliputi daftar nama siswa kelas $V$ baik laki-laki maupun perempuan, kriteria ketuntasan minimal mata pelajaran Matematika, dan gambar saat proses pembelajaran sedang berlangsung di kelas V SDN Mpuri tahun ajaran 2021/2022.

Pengujian hipotesis penelitian ini dilakukan untuk mengetahui apakah terdapat pengaruh yang signifikan antara teknik ice breaking terhadap hasil belajar siswa pada mata pelajaran Matematika kelas V SDN Mpuri. Untuk mempermudah melihat bagaimana pengaruh variabel bebas terhadap variabel terikat, dalam penelitian ini digunakan uji-t dengan cara membandingka $t_{\text {hitung }}$ dengan 
$t_{\text {tabel }}(\alpha=5 \%)$. Uji-t yang dimaksudkan adalah uji-t dua sampel Paired sample $t$-test menggunakan pengujian dua pihak (two tail test), adapun kemungkinan hasil penelitian sebagai berikut:

a. Jika $t_{\text {hitung }}>t_{\text {tabel }}(\alpha=5 \%)$ maka t hitung yang diperoleh signifikan (hipotesis alternatif/ Ha diterima dan hipotesis nol/Ho ditolak).

b. Jika $t_{\text {hitung }} \leq t_{\text {tabel }}(\alpha=5 \%)$ maka t hitung yang diperoleh signifikan (hipotesis alternatif/ Ha ditolak dan hipotesis nol/Ho diterima).

Kemungkinan hasil penelitian signifikansi SPSS sebagai berikut:

a. Jika sig $>0,05$ maka Ho diterima.

b. Jika sig < 0,05 maka Ho ditolak.

\section{HASIL DAN PEMBAHASAN}

\section{A. Hasil Penelitian}

Hasil penelitian diperoleh dari hasil tes hasil belajar siswa kelas V pada mata pelajaran Matematika yang dilakukan di awal sebelum perlakuan atau treatment pada kelas eksperimen dengan menggunakan teknik ice breaking. Tes berbentuk isian sebanyak 15 butir soal, serta instrument lain yaitu Rencana Pelaksanaan Pembelajaran (RPP), Lembar Kerja Siswa (LKS) yang telah divalidasi oleh validator ahli serta penilaian aktivitas siswa dengan menggunakan Lembar Observasi Aktivitas Siswa. Berdasarkan lokasi penelitian, fokus dalam penelitian ini adalah bagaimana meningkatkan hasil belajar di kelas V SDN Mpuri. Penelitian ini menitik beratkan pada bagaimana meningkatkan hasil belajar matematika siswa dengan menggunakan teknik Ice Breaking. Proses pembelajaran dilaksanakan 6 kali pertemuan. Pada pertemuan pertama siswa diberi tes awal (pretest) terlebih dahulu untuk mengukur kemampuan awal siswa mengenai pembelajaran matematika. Pada pertemuan selanjutnya pemberian materi pembelajaran dan pemberian treatment dengan menggunakan teknik ice breaking.

\section{B. Pembahasan}

Hasil statistik yang berkaitan dengan nilai tes awal (pretest) siswa pada kelas V yakni kelas yang diberikan perlakuan menggunakan teknik ice breaking dapat disajikan sebagai berikut: Deskripsi skor nilai tes awal (pretest) siswa pada kelas $\mathrm{V}$ dengan jumlah sampel 30 yaitu memiliki rata-rata 56,43 dengan nilai median 54,60. Sedangkan standar deviasi yang diperoleh yaitu 10,57 dengan nilai terendah 36,4 dan nilai tertinggi 78,8. Selain itu, diperoleh juga besar nilai variance pada data ini yaitu 111,87. Presentase skor hasil Belajar Siswa (Pretest) sebelum penggunaan teknik ice breaking. Dari hasil pretest di atas menunjukkan tidak ada siswa yang berada pada kategori sangat baik. 2 dari 30 siswa dengan presentase 6,67\% berada pada kategori baik, 12 dari 30 siswa dengan presentase 40\% berada pada kategori cukup, 14 dari 30 siswa dengan presentase 46,6\% berada pada kategori kurang dan 2 dari 30 siswa dengan presentase $6,67 \%$ berada pada kategori sangat kurang. Berdasarkan data tersebut dapat disimpulkan bahwa hasil belajar siswa sebelum penggunaan teknik ice breaking pada mata pelajaran Bahasa Indonesia masih tergolong cukup hal ini dapat dilihat pada nilai rata-rata (mean) secara keseluruhan berjumlah 56,43.

Deskripsi hasil belajar matematika siswa dengan jumlah sampel 30 siswa memiliki rata-rata yaitu 82,13 dengan nilai median 81,85. Sedangkan standar deviasi yang diperoleh yaitu 7,09 dengan nilai terendah 72,1 dan nilai tertinggi 90,9. Selain itu, diperoleh juga besar nilai variance pada data ini yaitu 50,34. Hasil posttest menunjukkan tidak ada siswa yang berada pada kategori cukup, kurang dan sangat kurang. 7 dari 30 siswa dengan presentase 23,3\% berada pada kategori sangat baik, 23 dari 30 siswa dengan presentase $76,6 \%$ berada pada kategori baik. Berdasarkan data tersebut dapat disimpulkan bahwa hasil belajar matematika siswa setelah penggunaan teknik ice breaking pada mata pelajaran matematika berada pada kategori 
baik hal ini dapat dilihat pada nilai rata-rata (mean) secara keseluruhan berjumlah 82,13.Berdasarkan hasil penelitian yang telah dilakukan bahwa penggunaan teknik ice breaking dapat mempengaharuhi hasil belajar siswa kelas V SDN Mpuri, yang dapat dilihat dari perbandingan tes hasil belajar pretest dan posttest. Tes hasil belajar yang didapatkan siswa pada saat pretest paling banyak berada pada kategori cukup dengan persentase $40 \%$ dan sangat kurang dengan persentase $46,6 \%$. saat posttest paling banyak berada pada kategori baik dengan persentase $76,6, \%$. Dari hasil ini disimpulkan bahwa penggunaan teknik ice breaking dapat mempengaharui hasil belajar. Pengujian hipotesis ini dilakukan dengan cara membandingkan antara $t_{\text {hitung }}$ dan $t_{\text {tabel }}$ apabila $t_{\text {hitung }}>t_{\text {tabel }}$ maka Ho ditolak dan Ha diterima, dan $t_{\text {hitung }} \leq t_{\text {tabel }}$ maka Ho diterima dan Ha ditolak. Berdasarkan data yang telah diperoleh nilai $t_{\text {hitung }}$ yang diperoleh yaitu 0,017 . Dengan membandingkan nilai $t_{\text {hitung }}$ dengan $t_{\text {tabel }}$ pada taraf signifikansi $5 \%$ maka dicapai $0,017<0,05$ artinya bahwa terdapat perbedaan signifikan sebelum dan sesudah pemberian treatment. Sehingga H0 diterima dan Ha ditolak, artinya ada pengaruh penerapan teknik Ice Breaking terhadap hasil belajar matematika pada siswa kelas $\mathrm{V}$ SDN Mpuri.

\section{SIMPULAN DAN SARAN}

\section{A. Simpulan}

Berdasarkan hasil penelitian, analisis data dan pembahasan, maka dapat ditarik beberapa kesimpulan sebagai berikut:

1. Teknik ice breaking dilaksanakan dengan 7 langkah-langkah pelaksanaan yaitu (a) Membentuk kelompok, (b) penjelasan tujuan permainan, (c) mendiskusikan tema, (d) peneliti menyiapkan catatan, (e) siswa mulai bercerita, (f) peneliti mengatur cerita jangan sampai selesai sebelum siswa terakhir memberikan cerita, (g) cerita berakhir apabila semua siswa sudah bercerita minimal satu kata.

2. Ada pengaruh antara teknik ice breaking terhadap hasil belajar matematika siswa kelas V SDN Mpuri.

\section{B. Saran}

Berdasarkan hasil penelitian yang telah dilakukan, salah satu saran yang dapat dikemukakan oleh peneliti yaitu diharapkan guru dapat menggunakan aplikasi pengenalan pada tingkatan sekolah dasar menggunakan macromedia flash untuk mempermudah penyampaian materi tentang huruf hijaiyah agar menjadi daya tarik siswa sehingga mampu meningkatkan pengetahuan, keterampilan dan motivasi belajar.

\section{DAFTAR RUJUKAN}

Asmedy, A. (2021). Perbandingan Hasil Belajar Matematika Menggunakan Model Pembelajaran Means Ends Analysis (MEA) dengan Model Pembelajaran Konvensional Pokok Bahasan Dimensi Tiga. Ainara Journal (Jurnal Penelitian Dan PKM Bidang Ilmu Pendidikan), 2(2), 124132. https://doi.org/10.54371/ainj.v2i2.42

Asmedy, A. (2021). Perbedaan Hasil Belajar Siswa yang Diajar Menggunakan Model Pembelajaran Soal Terbuka dengan Model Pembelajaran Konvensional. Ainara Journal (Jurnal Penelitian Dan PKM Bidang Ilmu Pendidikan), 2(2), 79-88. https://doi.org/10.54371/ainj.v2i2.36

Chatib, Munif. 2013. Gurunya Manusia. Bandung: Kaifa.

Dananjaya, Utomo. 2013. Media Pembelajaran Aktif Edi si III. Bandung: Nuansa Cendikia.

Ika Febriandari. Pengaruh kreativitas guru dalam menerapkan ice breaking dan motivasi belajar terhadap hasil belajar siswa sekolah dasar. 2018. Jurnal Riset dan Konseptual Vol.3 No 4

Kasmadi. $\quad$ 2014. Panduan Modern Penelitian Kuantitatif.Bandung: Alfabeta. 
Porter, De Bobby. 2012. Quantum Learning Membiasakan Belajar Nyaman dan Menyenangkan.Jakarta: Kaifa Learning.

Prananda, G \& Hadiyanto. 2019. Korelaasi antara Motivasi Belajar dengan hasil Belajar peserta didik dalam pembelajaran IPA sekolah dasar. Jurnal basicedu, 3(3), 909-915.rbgai

Rusman, 2015. Pembelajaran Tematik Terpadu. Jakarta : Raja Grafindo Persada.

Sapri. Implementasi dan manfaat Ice breaking unutk meningkatkan minat Belajar Siswa Sekolah dasar. 2022. Vol 6 No 1

Srirahmawati, I. (2021). Peran Guru Sebagai Fasilitator dalam Mengasah Penalaran Matematika Siswa SDN 29 Dompu Tahun Pembelajaran 2020/2021. Ainara Journal (Jurnal Penelitian Dan PKM Bidang Ilmu Pendidikan), 2(2), 114-123. https://doi.org/10.54371/ainj.v2i2.40

Sunarto, 2012, Icebreaker dalam Pembelajaran Aktif. Surakarta : Cakrawala 